\title{
NR2C2 Gene
}

National Cancer Institute

\section{Source}

National Cancer Institute. NR2C2 Gene. NCI Thesaurus. Code C106597.

This gene is involved in hormone-dependent transcriptional regulation. 